\title{
DC Motor Speed Control Using Mamdani Fuzzy Logic Based on Microcontroller
}

\author{
Sumardi Sadi \\ Teknik Elektro, Fakultas Teknik, Universitas Muhammadiyah Tangerang \\ Jl. Perintis Kemerdekaan I No.33, Cikokol, Tangerang, Banten 15118 \\ e-mail :mardiesadi99@gmail.com
}

\begin{abstract}
$D C$ motors are included in the category of motor types that are most widely used both in industrial environments, household appliances to children's toys. The development of control technology has also made many advances from conventional control to automatic control to intelligent control. Fuzzy logic is used as a control system, because this control process is relatively easy and flexible to design without involving complex mathematical models of the system to be controlled. The purpose of this research is to study and apply the fuzzy mamdani logic method to the Arduino uno microcontroller, to control the speed of a DC motor and to control the speed of the fan. The research method used is an experimental method. Global testing is divided into three, namely sensor testing, Pulse Width Modulation (PWM) testing and Mamdani fuzzy logic control testing. The fuzzy controller output is a control command given to the DC motor. In this DC motor control system using the Mamdani method and the control system is designed using two inputs in the form of Error and Delta Error. The two inputs will be processed by the fuzzy logic controller (FLC) to get the output value in the form of a PWM signal to control the DC motor. The results of this study indicate that the fuzzy logic control system with the Arduino uno microcontroller can control the rotational speed of the DC motor as desired.
\end{abstract}

Keywords: DC Motor, Fuzzy Logic, Arduino Uno, Fan

\section{INTRODUCTION}

DC motor speed regulation is needed for various purposes, whether for small, medium or large industrial needs. A company or industry uses a motion system, which works using a propulsion device requires at least a motor, be it a DC motor or an AC motor. For large power, or large loads use an AC motor and small loads use a DC motor.

The problem is DC motor rotation settings are not as desired. The solution is make the desired rotation using a fuzzy system. Benefits of DC motor settings for drives are adjustable. The advantage is the output achieved with less error. The use of dc motors widely for operational completeness in the industry, for example the use of a dc motor speed in a win turbine emulator (WTE) (Li et al. 2007). DC motor arrangement with PWM via personal computer (Hidayati \& Prasetyo, 2016). DC motor arrangement for Honey Extract (Ardhika et al. 2014)

DC motor regulation without the use of a controller, but applying a tap on the motor windings. In this case the control uses a microcontroller in the form of a fuzzy logic system, because the machine settings are made uncertain.

The problem that exists today is setting the speed of a dc motor using switch to adjust the motor speed, in low, medium and high speeds using three buttons. An example application of this is a fan sold commercially.

DC motor settings can be done in various ways, including: using PID (Ali 2012), setting the speed of a dc motor without position and speed sensors with control using the DSP-TMS320C25 software resulting in DC motor settings with stable conditions (Matsui 1992), and controlling using fuzzy (Yulianta et al. 2015). In this study, the DC motor 
control uses Fuzzy Mamdani logic. The aim of this research, DC motor speed research to adjust the speed desired by the user.

\section{RESEARCH METHODS}

The method used in this experiment is using the experimental method.

\section{Tools and Materials}

Table 1 Tools and functions

\begin{tabular}{|c|c|c|}
\hline No & Alat & Fungsi \\
\hline 1. & Laptop & $\begin{array}{l}\text { Used for programming and creating fuzzy } \\
\text { logic as needed. }\end{array}$ \\
\hline 2. & Screw & Used for loading and unloading tools. \\
\hline 3. & $\begin{array}{l}\text { Software } \\
\text { Sketchup and } \\
\text { matlab }\end{array}$ & $\begin{array}{l}\text { Used to design new products and create } \\
\text { coding as needed. }\end{array}$ \\
\hline
\end{tabular}

Table 2 Materials and functions

\begin{tabular}{cll}
\hline No & \multicolumn{1}{c}{ Bahan } & \multicolumn{1}{c}{ Fungsi } \\
\hline 1 & Keypad & As input to enter the desired motor speed. \\
2 & Arduino Uno & As Controller \\
3 & Liquid Crystal & As an indicator to display ongoing processes \\
4 & L298N Modul & $\begin{array}{l}\text { As a DC motor speed regulator according to the } \\
\text { input entered }\end{array}$ \\
5 & DC Motor & As a rotator of the fan \\
\hline
\end{tabular}

\section{Product Design}

Product designs made using SketchUp with the main components, the control circuit and a fan.

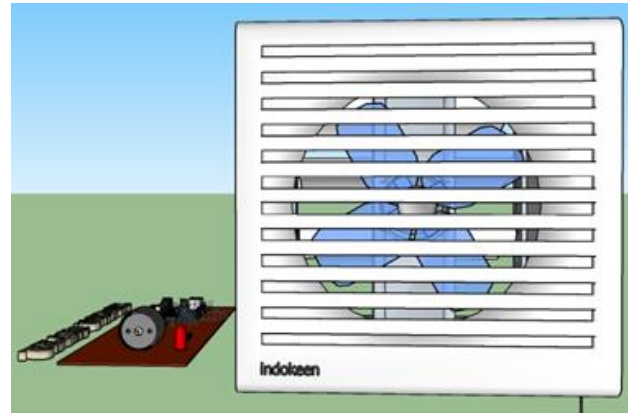

a) Front View

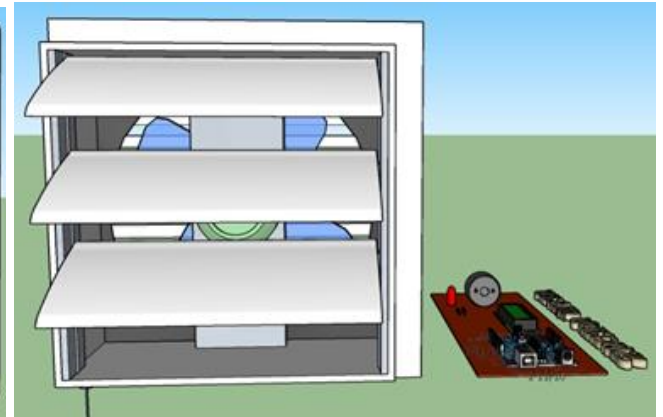

b) Back view 
JT : Jurnal Teknik

P-ISSN: 2302-8734

E-ISSN: 2581-0006
Vol. 9 No. 2 Th. 2020

Pages : 96 - 104

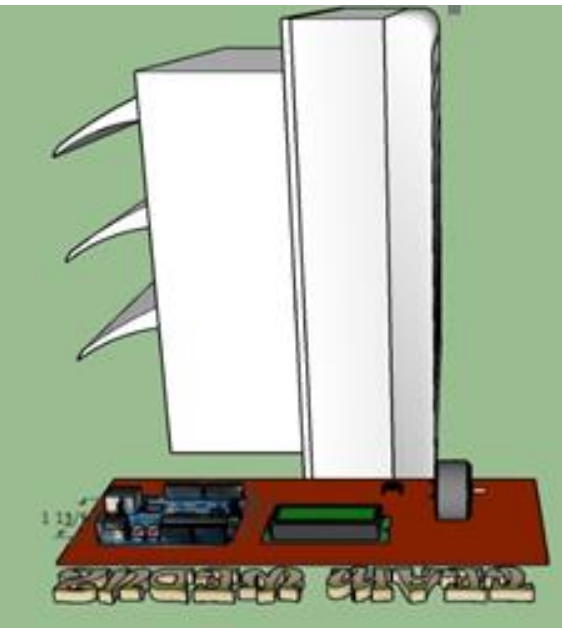

c) Side View

Figure 1 Product Design

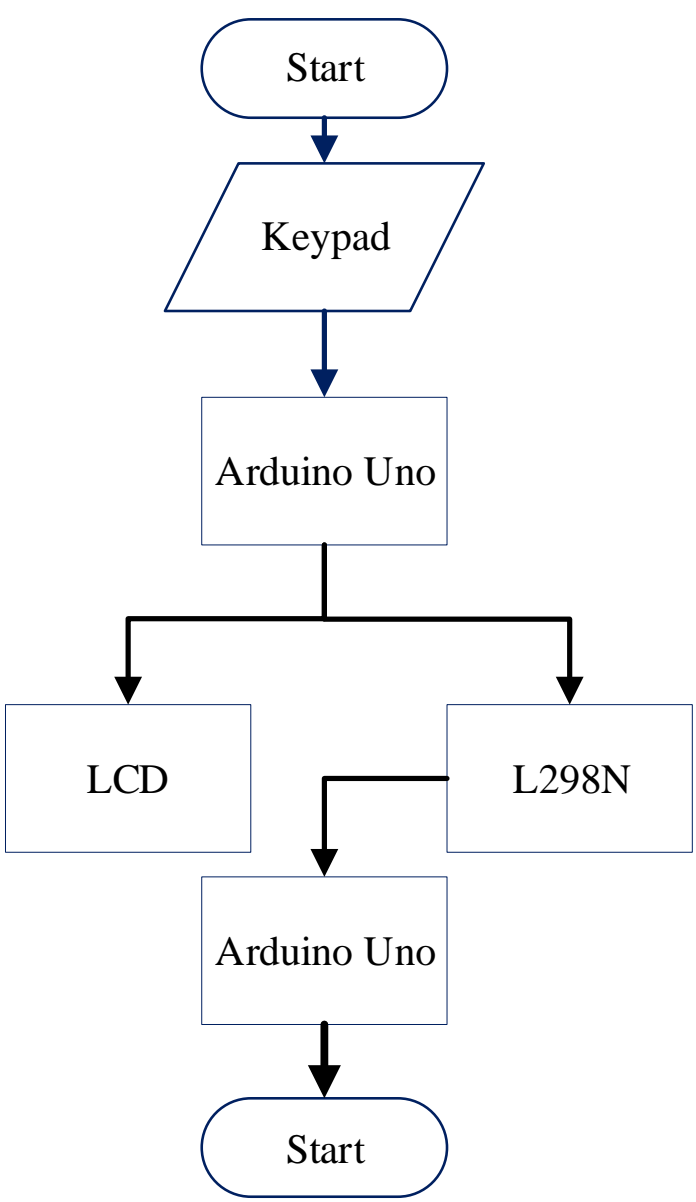

Figure 2 DC Motor Control Flowchart 


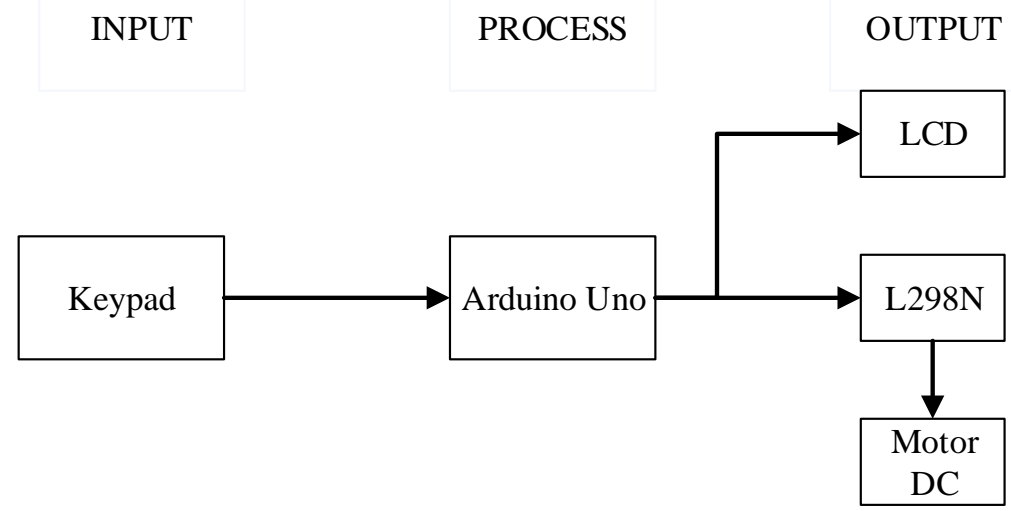

Figure 3 Block Diagram System

The DC motor used a DC motor contained in the fan, where the DC motor control step uses a switch, but with this control device, the DC motor control uses a keypad with a fuzzy logic system.

The way this DC motor speed setting works to enter the input in the form of a number on the keypad which aims to set how much the desired motor speed will then be processed through the Arduino uno, which then produces the motor speed output according to the desired input. The amplification of the microcontroller uses the L298N DC motor driver module.

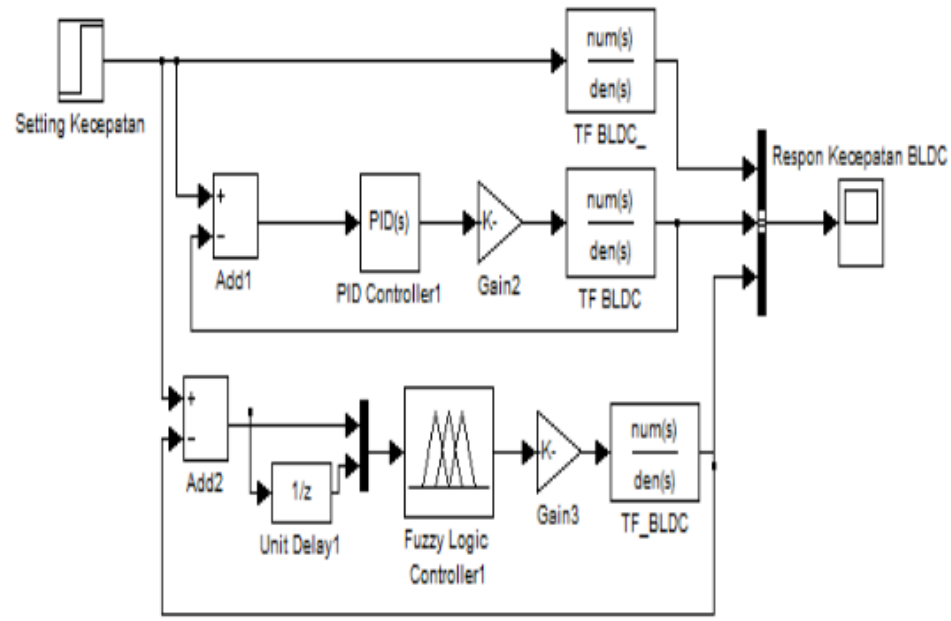

Figure 4 Fuzzy Work System

Source: (Yulianta et al., 2015)

\section{Result}

\section{RESULTS AND DISCUSSION}

Test results using matlab software, resulting in the simulation produced using the MatLab program are depicted in Figure 5 to Figure 11. Input output settings, resulting in a rotation of output, a value can rotate the DC motor with speed according from keypad. 
JT : Jurnal Teknik

P-ISSN: 2302-8734

JT

Vol. 9 No. 2 Th. 2020

E-ISSN: 2581-0006

FT UMT

Pages : 96 - 104

December 2020

FIS Editor: Untitled

$-\square \times$

File Edit View

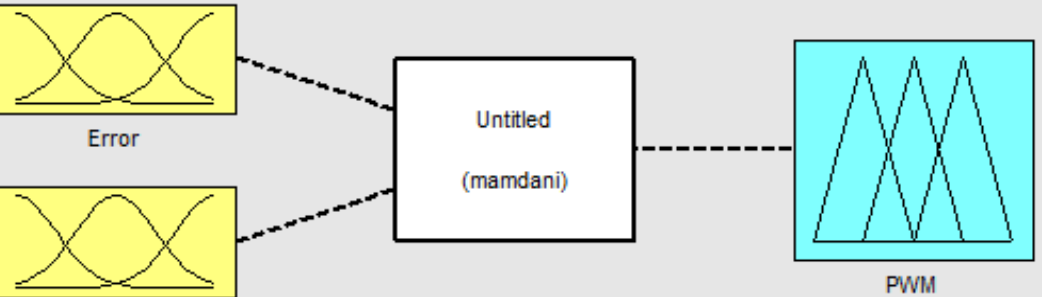

DeltaError

\begin{tabular}{|lll|}
\hline FIS Name: & Untitled & FIS Type: \\
\hline
\end{tabular}

And method

Or method

$\min$

Current Variable

Implication

Aggregation

$\max$

$\min$

Defuzzification

$\max$

centroid

Name

Type

Range

System "Untitled": 2 inputs, 1 output, and 0 rules

Figure 5 Input and output

Membership Function Editor: Untitled

$-\square \times$

File Edit View

FIS Variables

$\square \square$

Error PWM

X

DeltaError

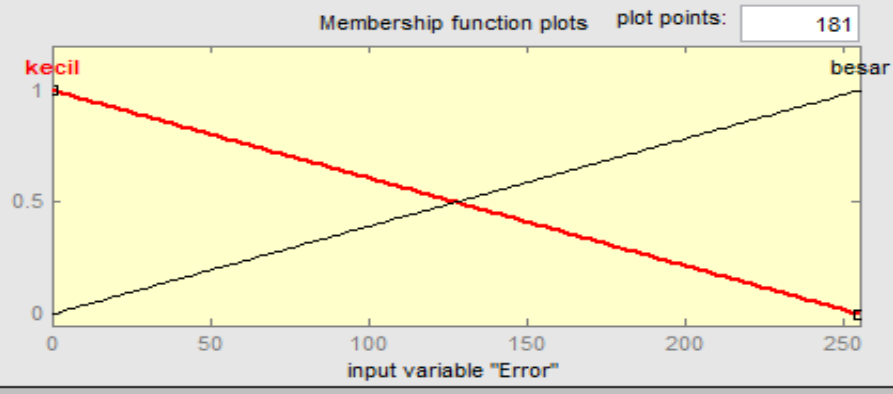

Current Variable

Name

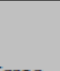

(

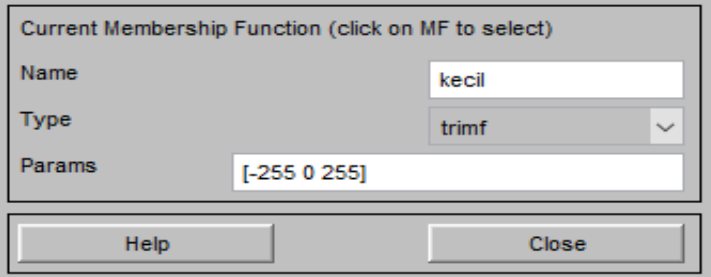

Display Range

input

Type

255]

Selected variable "Error"

Figure 6 Error Value 
JT : Jurnal Teknik

P-ISSN: 2302-8734

JT

Vol. 9 No. 2 Th. 2020

E-ISSN: 2581-0006

FT UMT

Pages : 96 - 104

December 2020

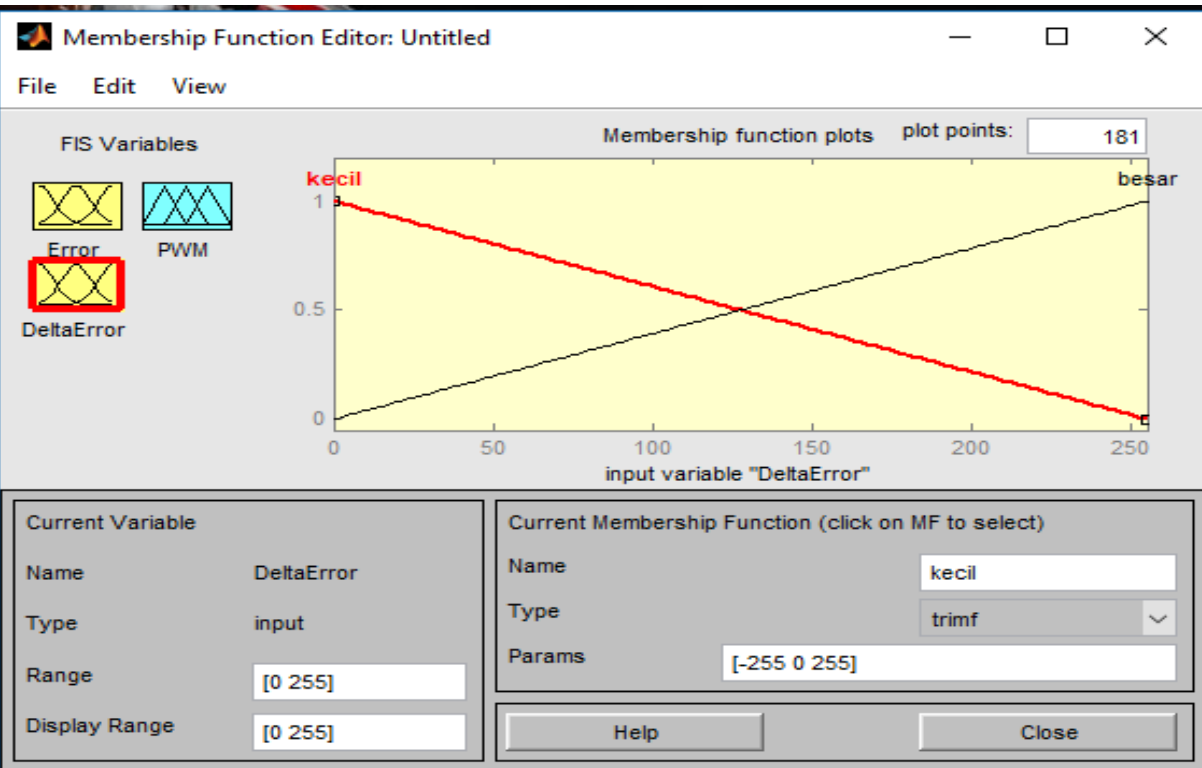

Selected variable "DeltaError"

Figure 7 Delta Error Value

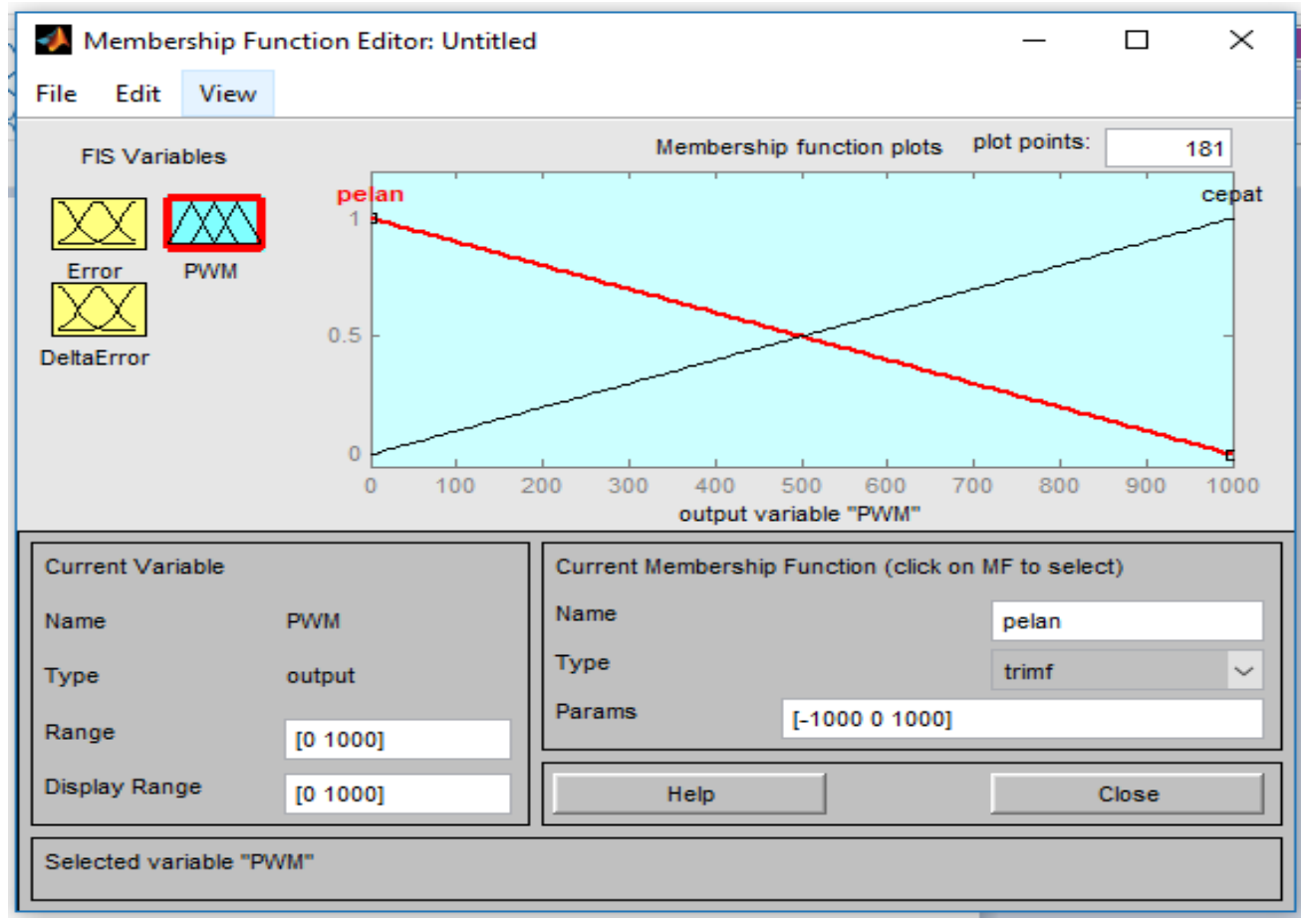

Figure 8 Membership 
JT : Jurnal Teknik

P-ISSN: 2302-8734

File Edit View Options

1. If (Error is kecil) and (DeltaError is kecil) then (PWM is pelan) (1)

2. If (Error is kecil) and (DeltaError is besar) then (PWM is pelan) (1)

3. If (Error is besar) and (DeltaError is kecil) then (PWM is cepat) (1)

4. If (Error is besar) and (DeltaError is besar) then (PWM is cepat) (1)

\begin{tabular}{l|l|l|}
\hline \multicolumn{1}{|l|}{ Error is } & \multicolumn{1}{c}{ and } \\
\hline $\begin{array}{l}\text { kecil } \\
\text { besar } \\
\text { none }\end{array}$
\end{tabular}

$\square$ not

$\square$ not

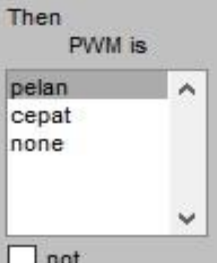

Connection

Oor

(O) and

Weight:

The rule is added

1

Delete rule Add rule Change rule

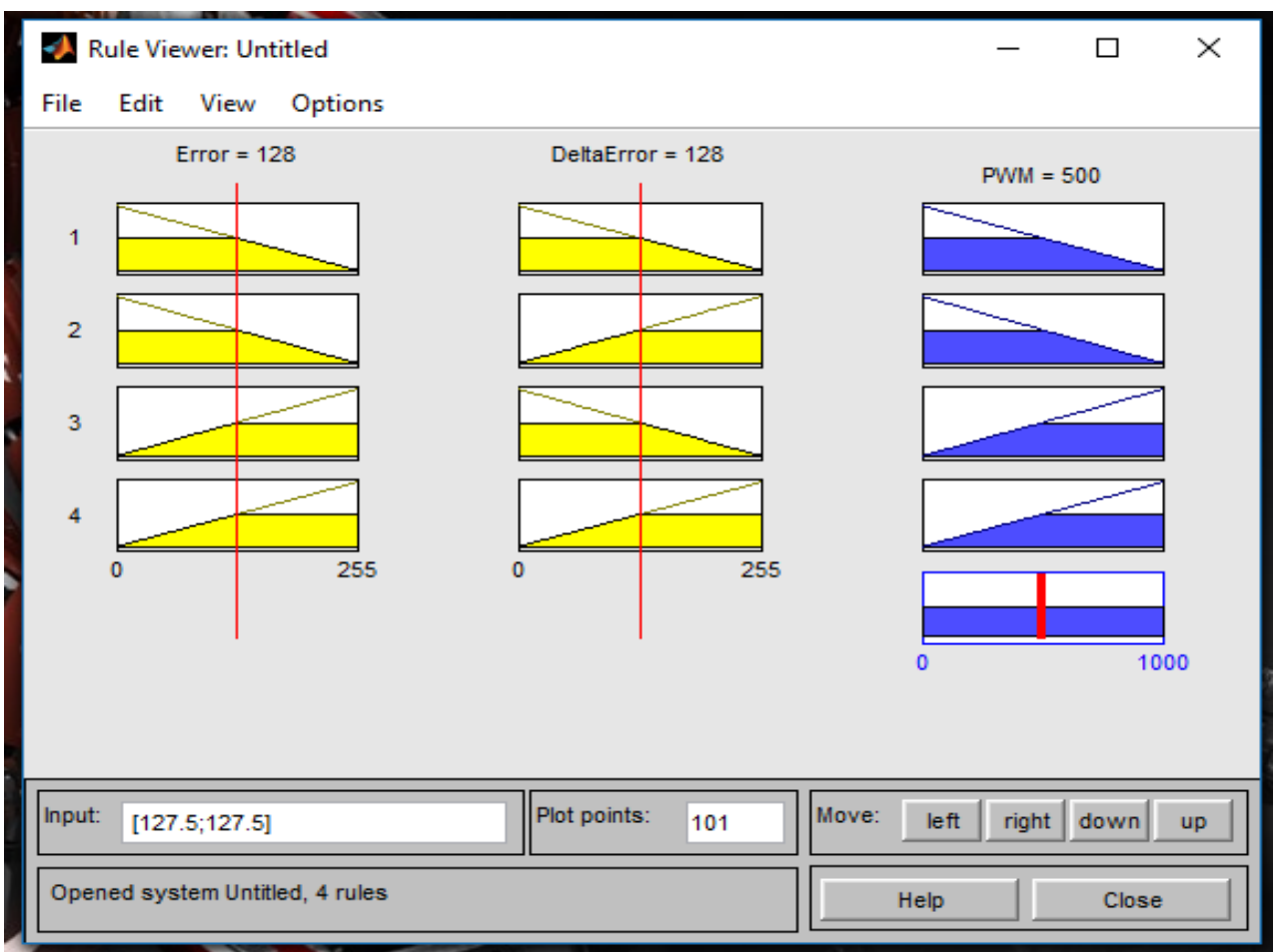

Figure 10 Input settings with error and delta error 


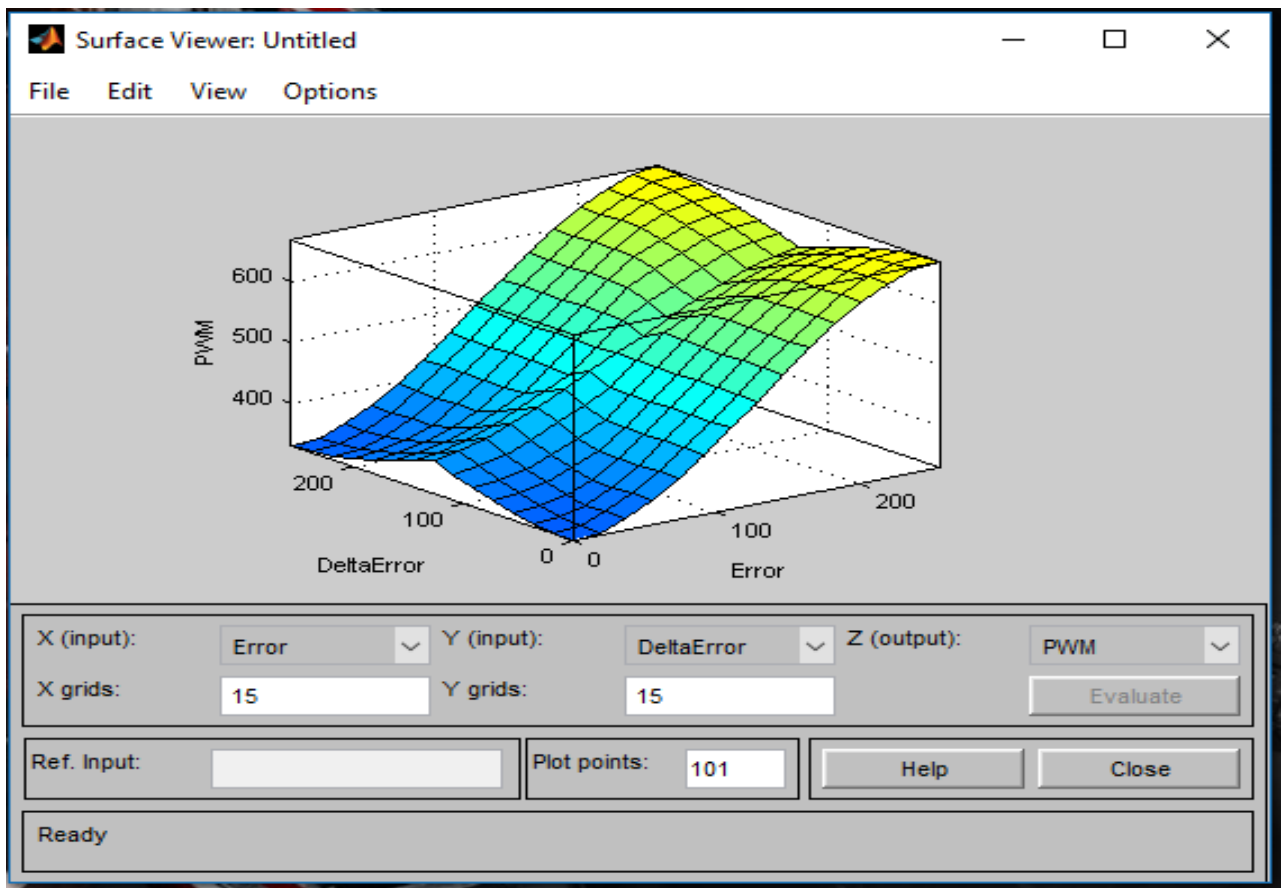

Figure 11 Surface Graph

Table 3 Fuzzy Process Test Results

\begin{tabular}{|c|c|c|c|}
\hline No & Error & Delta Error & Output \\
\hline 1 & 0 & 0 & 333,33 \\
\hline 2 & 30 & 20 & 346,09 \\
\hline 3 & 70 & 50 & 394,9 \\
\hline 4 & 105 & 90 & 456,34 \\
\hline 5 & 125 & 140 & 495,1 \\
\hline 6 & 160 & 175 & 562,35 \\
\hline 7 & 180 & 200 & 597,12 \\
\hline 8 & 200 & 100 & 600,77 \\
\hline 9 & 234 & 120 & 660,42 \\
\hline 10 & 250 & 180 & 641,2 \\
\hline
\end{tabular}

\section{Conclusion}

\section{CONCLUSIONS AND SUGGESTIONS}

Arduino Uno as a control on the fan is able to move the speed of a DC motor with the help of the L298N motor driver at a slow to fast speed according to the input entered. The speed of the DC motor on the fan that is controlled by the Arduino uno can make it easier for users to determine the speed of the fan according to the needs of the user.

Suggestion

The keypad for DC motor rotation settings can be changed using the Blynk application so that its use is more practical and easier to use by adding Bluetooth as its connectivity. For programs on Arduino, you can use Labview to code it and can be used as an HMI to adjust the speed of the DC motor on the fan. 


\section{BIBLIOGRAPHY}

Ali, M. (2012). Kontrol Kecepatan Motor DC Menggunakan PID Kontroler Yang Ditunning Dengan Firefly Algorithm. Intake: Jurnal Penelitian Ilmu Teknik Dan Terapan, 3(2), 1-10.

Ardhika, R., Yudaningtyas, E., \& Nusantoro, G. D. (2014). Sistem pengaturan kecepatan Motor DC pada alat ektraksi madu menggunakan kontrol logika fuzzy. Jurnal Mahasiswa TEUB, 2(1), $1-7$. http://elektro.studentjournal.ub.ac.id/index.php/teub/article/view/187

Hidayati, Q., \& Prasetyo, M. E. (2016). Pengaturan Kecepatan Motor DC dengan Menggunakan Mikrokontroler Berbasis Fuzzy-PID. JTT (Jurnal Teknologi Terpadu), 4(1), 1-5. https://doi.org/10.32487/jtt.v4i1.123

Li, W., Xu, D., Zhang, W., \& Ma, H. (2007). Research on wind turbine emulation based on DC motor. ICIEA 2007: 2007 Second IEEE Conference on Industrial Electronics and Applications, June, 2589-2593. https://doi.org/10.1109/ICIEA.2007.4318881

Matsui, N. (1992). Brushless dc Motor Control without Position and Speed Sensors. IEEE TRANSACTIONS ON INDUSTRY APPLICATION, 28(1), 120-127.

Yulianta, A. D., Hadi, S. P., \& Suharyanto. (2015). Pengendalian Kecepatan Motor Brushless dc Menggunakan Metode Logika Fuzzy. Jurnal Sains, Teknologi Dan Industri, 8(1), 1-9. 